\title{
Provision of land resources for the sustainable sengon raw material industry in Bedadung Jember Watershed
}

Yaumil Zahro Fadila ${ }^{\mathrm{a}}$, Idah Andriyani ${ }^{\mathrm{b}}$, Bambang Herry Purnomo ${ }^{\mathrm{c}}$, Achmad Fauzan Masudi $^{\mathrm{a}}$

a Management of Water Resources Agriculture/Natural Environment Study Program, Postgraduate, Jember University, 68121, Indonesia [+62 85235263298]

${ }^{\mathrm{b}}$ Agricultural Engineering Departement, Agricultural Technology Faculty, Jember University, 68121, Indonesia

${ }^{c}$ Agricultural Industrial Technology Study Program, Agricultural Technology Faculty, Jember University, 68121, Indonesia

Article Info:

Received: 06 - 08 - 2021

Accepted: 13 - 10 - 2021

Keywords:

Agroindustry, Bedadung Watershed, land suitability, sengon, system information geography (SIG)

Corresponding Author: Yaumil Zahro Fadila Management of Water Resources Agriculture/Natural Environment Study Program, Postgraduate, Jember University; Tel. +6285235263298

Email:

yaumilzahro.13@gmail.com

\begin{abstract}
Sengon (Paraserianthes falcataria) is a mainstay commodity as an industrial raw material with high economic value. The domino effect that appears is the increase in the area of sengon land and causes changes in land use. Land conversion will be vulnerable to erosion and increase the level of erosion hazards. Inappropriate land changes will also threaten the sustainability of the agroindustry; therefore, it is necessary to evaluate the suitability of the sengon plant land. This study aims to identify the suitability of sengon land in the Bedadung watershed for sustainable agroindustry development. There are 14 parameters analyzed, and the method used is matching and overlay. The results of land suitability analysis on dominant sengon plants were categorized as S3 "marginally appropriate" (48.07\%). The limiting factors for sengon plants are rainfall and soil solum. Overcome the low rainfall needed to build a dam or reservoir, but these repairs require a lot of funds and time. The preferred solution for farmers to get additional water is to use water pumps and irrigation canals. Meanwhile, efforts to improve soil depth are complicated because it takes a long time. Thus, the sengon commodity in Jember Regency will experience sustainability.
\end{abstract}

How to cite (CSE Style $8^{\text {th }}$ Edition):

Fadila YZ, Andriyani I, Purnomo BH, Masudi AF. 2021. Provision of land resources for the sustainable sengon raw material industry in Bedadung Jember Watershed. JPSL11(3): 453-462. http://dx.doi.org/10.29244/jpsl.11.3.453-462.

\section{INTRODUCTION}

The development of the wood industry in Indonesia is one of the driving forces for improving the national economy and increasing state income from the forestry sector. This effort requires a lot of raw wood materials that come from outside the forest area. The government and industry develop an Industrial Plantation Forest program. This program is used to increase the potential and quality of forest products through an intensive silvicultural system to meet the demand for raw forest materials for industrial use (Rimbakita.com, 2021). There are several types of plants used in this program, namely sengon (Paraserianthes falcataria), balsa (Ochroma pyramidale), and jabon (Neolamarckia cadamba).

Sengon plants become high commodities as industrial raw materials. The economic value obtained by farmers makes the interest in planting sengon high. Sengon tree is a fast-growing species of wood (fast-growing species), management is relatively easy, the nature of the wood belongs to a strong class, and market demand continues to increase (Nugroho and Salamah, 2015). The domino effect that arises is the increasing area of sengon land developed by farmers and causing changes in land use, from plantation land and even rice fields 
to sengon plantations. It affects the ecology of the environment, especially on land prone to erosion. Planting sengon on the erosion-prone ground can increase the level of erosion hazard that exists. Based on the initial observations, $45.6 \%$ of farmers in the Bedadung watershed only see the economic value of planting sengon without paying attention to land use conditions that are not by planting requirements, which will be a separate threat to the sustainability of the agroindustry made from sengon.

Based on the preliminary survey, sengon plants can cause erosion, especially in watershed areas. It is because the fibrous roots of sengon are unable to hold the soil, especially on steep slopes. In addition, the canopy cover on sengon is less dense so that if there is heavy rain, erosion will occur, so it is necessary to have other plants that can protect the soil. Bedadung watershed is one of the 108 National Priority Watersheds in forest and land rehabilitation activities, and this is due to the steep slope and low vegetation cover level (Wibisono, 2021). The Andriyani et al. (2020) statement reinforces that the Bedadung watershed's erosion rate is 160.57 tons/ha/year, in moderate condition. Erosion can also cause a new problem, namely land degradation. Land degradation is a process of decreasing land productivity which is temporary or permanent. Degraded land is often called unproductive land or critical land (Dariah and Wahyunto, 2014). Thus, it is necessary to evaluate the land to optimize sustainable land use (Harahap et al., 2020).

Land Evaluation is an effort to assess the level of suitability of land for a particular use. The function of land evaluation is to reorganize existing land uses and help facilitate planning policies so that land can be used efficiently. An accurate land suitability evaluation analysis can be used as a basis for communities to develop their lands. This study aims to identify the land suitability of sengon plants in the Bedadung watershed. This information is used to create sustainable agroindustry. The mechanism for evaluating land suitability is to compare the conditions for growing sengon plants with the characteristics of the land in the study location. The data was obtained from secondary data based on the results of previous research, related agencies, and primary data in the form of measurements and field surveys.

\section{METHOD}

\section{Study Area}

The study was conducted for four months, starting from February to June 2021 (Figure 1). The study area was undertaken in the Bedadung watershed, which has an area of 125306.83 ha. Bedadung watershed is

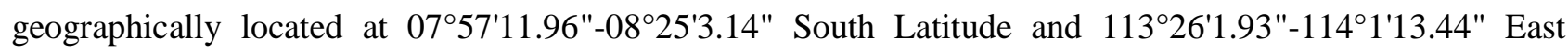
Longitude. Administratively, the Bedadung watershed includes Jember Regency (94.89\%), Bondowoso Regency (4.22\%), and Probolinggo Regency (0.89\%) (Wibisono, 2021). The chemical and physical properties of the soil were analyzed at the Laboratory of Soil Physics and Soil Chemistry, Department of Soil, Faculty of Agriculture, University of Jember.

\section{Data Collection}

Determination of soil sampling for analysis was collected randomly from the $0-15 \mathrm{~cm}$ soil layer (Liu et al., 2014). Analysis of soil properties was carried out through continuous sampling of soil. The samples that have been taken are then taken to the laboratory for research, such as soil texture, organic $\mathrm{C}$, soil CEC, $\mathrm{pH}$, and NPK. Soil texture analysis using pipette method, C-organic was analyzed by Walkey \& Black method (Black, 1965), soil CEC was analyzed from ammonium acetate extract then distilled and titrated, soil acidity (pH) was measured by pH meter method (Van Reeuwijk, 1993), N was analyzed by Khendahl method, P by Olsen method, and $\mathrm{K}$ analysis by atomic absorption spectrophotometer.

Rainfall and dry month data were obtained from PU Water Resources, Jember Regency. Temperature data were obtained from the UPT PSDA Lumajang and then calculated using the Braak formula (Mohr et al., 1972). Erosion determination was computed using the USLE method with the overlay method. The following are the conditions for growing sengon plants based on Ritung et al. (2011) presented in Table 1. 


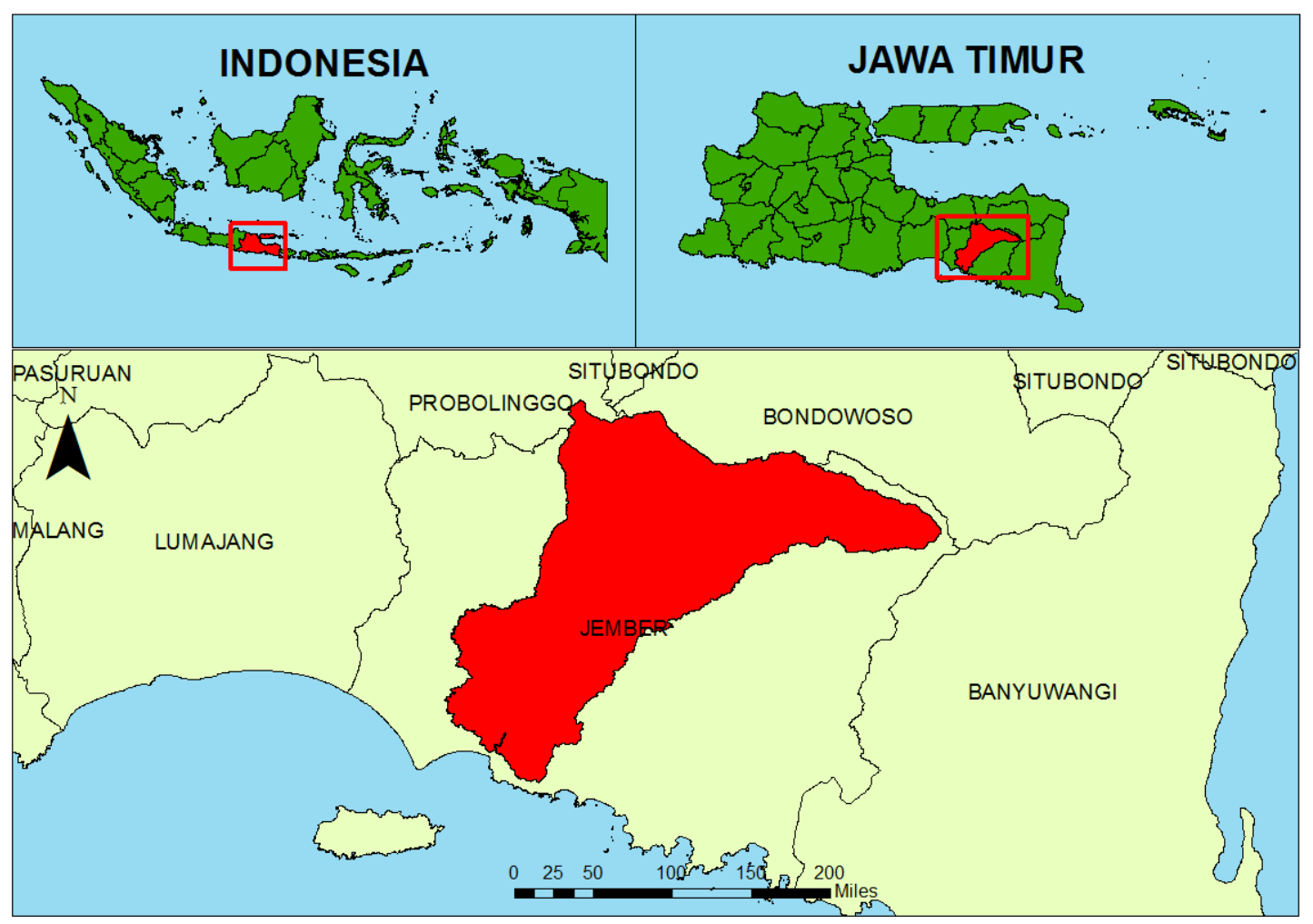

Figure 1 Map of research area location

\section{Data Analysis}

The data that has been processed is then recapitulated, then presented descriptively in tabulated form. Evaluation of land suitability was carried out using the matching method by comparing the characteristics of the land with the conditions for growing sengon plants (Table 1). Next, the matched data is overlaid using GIS with the help of a raster calculator. The overlay is the ability to place one map graphic on top of another map graphic and display the results on a computer screen or a plot (Qomaruddin et al., 2018). The next step is to reclassify. Reclassify functions as a classification or grouping of data derived from data that the raster calculator has analyzed. The following are the land evaluation classification criteria in Table 2.

\section{RESULTS AND DISCUSSION}

\section{Land Suitability Analysis}

The assessment results of the land suitability class of sengon plants are presented in the form of a map of each suitability criteria. Land suitability parameters based on Ritung et al. (2011) fourteen maps were analyzed using the matching method. Fourteen maps were then overlaid into land suitability maps for sengon plants. Furthermore, it is classified into land suitability classes which are divided into four, including S1 "Very Suitable", S2 "Sufficiently Appropriate", S3 "Marginal Appropriate", and N "Not Appropriate". S3 "Marginal Appropriate," namely land that has very heavy boundaries to maintain the level of management that must be carried out.

Temperature $\left({ }^{\circ} \mathrm{C}\right)$ is one of the climatological elements affecting land quality (Djaenudin et al., 2011). Temperature can also determine the chemical and physical properties of the soil, and this is because high temperatures will increase the speed of weathering or chemical formation (Wirosoedarmo et al., 2011). Bedadung watershed has an average temperature of $25.6^{\circ} \mathrm{C}$, included in the S1 class "Very Suitable" with the conditions for growing sengon plants. The temperature suitability assessment map is presented in Figure 2a. 
Table 1 Conditions for growing sengon

\begin{tabular}{|c|c|c|c|c|}
\hline \multirow{2}{*}{ Terms of Land Use Characteristics } & \multicolumn{4}{|c|}{ Land Suitability Class } \\
\hline & S1 & S2 & S3 & S4 \\
\hline \multicolumn{5}{|l|}{ Temperature (tc) } \\
\hline \multirow[t]{2}{*}{ - Average temperature $\left({ }^{0} \mathrm{C}\right)$} & $21-30$ & $30-34$ & - & $>34$ \\
\hline & & $19-21$ & & $<19$ \\
\hline \multicolumn{5}{|l|}{ Water Available (wa) } \\
\hline \multirow[t]{2}{*}{ - Rainfall (mm) } & $2500-3000$ & $3000-4000$ & - & $>4000$ \\
\hline & & $2000-2500$ & & $<2000$ \\
\hline - Dry months & $0-2$ & $2-4$ & - & $>4$ \\
\hline \multicolumn{5}{|l|}{ Oxygen Available (oa) } \\
\hline - Drainage & $\begin{array}{c}\text { Fine, } \\
\text { relatively } \\
\text { fast, medium }\end{array}$ & $\begin{array}{l}\text { Little late, } \\
\text { little early }\end{array}$ & Fast & $\begin{array}{l}\text { Late, too } \\
\text { late, hurry }\end{array}$ \\
\hline \multicolumn{5}{|l|}{ Rooting media (rc) } \\
\hline - Texture & $\begin{array}{l}\text { Medium, } \\
\text { slightly fine, } \\
\text { fine }\end{array}$ & $\begin{array}{l}\text { Rough, little } \\
\text { rough }\end{array}$ & $\begin{array}{c}\text { Very } \\
\text { smooth }\end{array}$ & \\
\hline - Solum Soil $(\mathrm{cm})$ & & $>100$ & $75-100$ & $<75$ \\
\hline \multicolumn{5}{|l|}{ Nutrient Retention (nr) } \\
\hline - KTK soil (cmol) & $>16$ & $5-16$ & $<5$ & \\
\hline \multirow[t]{2}{*}{ • $\mathrm{pH}$} & $5.5-7.0$ & $7.0-7.5$ & $7.5-8.0$ & $>8.0$ \\
\hline & & $5.0-5.5$ & $4.5-5.0$ & $<4.5$ \\
\hline - C-organic (\%) & $>0.4$ & $\leq 0.4$ & & \\
\hline \multicolumn{5}{|l|}{ Hara Available (na) } \\
\hline - $\mathrm{N}(\%)$ & Currently & Low & Very Low & \\
\hline - $\mathrm{P}(\mathrm{mg} / 100 \mathrm{~g})$ & Currently & Low & Very Low & \\
\hline$\bullet \mathrm{K}(\mathrm{mg} / 100 \mathrm{~g})$ & Currently & Low & Very Low & \\
\hline \multicolumn{5}{|l|}{ Erosion Hazard (eh) } \\
\hline - Slope (\%) & $<8$ & $8-15$ & $15-40$ & $>40$ \\
\hline - Erosion Hazard & Very heavy & $\begin{array}{c}\text { Heavy } \\
\text {-Currently }\end{array}$ & Light & Very Light \\
\hline
\end{tabular}

Source: Ritung et al. (2011)

Table 2 Land evaluation classification criteria

\begin{tabular}{ccc}
\hline No & Score & Class \\
\hline 1 & $14-21$ & N (Not Appropriate) \\
2 & $21-35$ & S3 (Marginal Appropriate) \\
3 & $35-49$ & S2 (Sufficiently Appropriate) \\
4 & $49-63$ & S1 (Very Suitable) \\
\hline
\end{tabular}

Spurce: Wirosoedarmo et al. (2011) 
The availability of water on the requirements of sengon plants depends on two parameters, namely rainfall and dry months. Rain is one of the essential elements of hydrology and climate. Precipitation is used to estimate water availability for plants, determine the boundary between the rainy season and the dry season, and control/anticipate floods or droughts (Romadlon and Hariyanto, 2014). Based on the data that has been analyzed, there are three rainfalls in the Bedadung watershed, including the S1 class "Very Suitable" covering $2.43 \%$ of the area, while the S2 class "Sufficiently Appropriate" covering an area of $18.76 \%$, and N "Not Appropriate" which has a place with low rainfall covering an area of $78.81 \%$. Rain in the Bedadung watershed is on average $<2000 \mathrm{~mm} /$ year, while sengon plants require $2500-4000 \mathrm{~mm} /$ year of rainfall. Rainfall for plants serves as a medium for providing plant water according to their needs (Wirosoedarmo et al., 2011).

Thus, it is necessary to provide rainfall water for the improvement of land suitability. According to (Winasis, 2019) the availability of rainfall water for plants is by making reservoirs or dams. The rainfall suitability assessment map is as shown in Figure 2b. Based on climate classification, the growth of sengon plants requires a certain length of dry months. The length of the dry month is one of the climatic parameters, which is calculated by calculating the number of months that have rainfall of less than $60 \mathrm{~mm}$ at each rain station. The Bedadung watershed has three land suitability classes specifically for the dry month parameter, including S1 "Very Suitable" as much as 95.94\% of the area, S2 "Sufficiently Appropriate" covering 3.05\%, and N "Not Appropriate" covering 1.01\%. Sengon plants require an appropriate minimum rainfall limit, 15 rainy days in the driest four months, and not too wet (Warisno, 2009). The dry month suitability assessment map can be seen in Figure 2c.

Plants need good drainage to provide aeration (Wirosoedarmo et al., 2011; Sudomo, 2012). If the drainage is good, then the plant roots can absorb nutrients and can develop properly. The land suitability class for drainage in the Bedadung watershed has two classes, namely S1 "Very Suitable" $73.06 \%$ and N "Not Appropriate" 26.94\%. The drainage suitability map can be seen in Figure 2d.

The rooting media on the terms of sengon plants have two parameters, namely soil texture and soil solum. Soil texture is the ratio between the fractions of sand, silt, and clay. Of the three bits, one of the essential fractions is clay because it provides soil nutrients. The negatively charged soil fraction in clay can bind cations needed by plants (Arunrat et al., 2020; Kome et al., 2019). According to Dou et al. (2016), dominant clay soil has more nutrients, affecting soil infiltration in binding water and holding and absorbing moisture. Soil texture suitability class in Bedadung watershed has three classes, namely S1 "Very Suitable" (81.20\%), S2 "Sufficiently Appropriate" (16.08\%), and S3 "Marginal Appropriate" (2.72\%). The soil texture suitability map is presented in Figure 2e. In the rooting media, soil solum is needed to determine the spread of the roots of the plants being evaluated. There are two classes of suitability for soil solum in the Bedadung watershed, namely S3 "Marginal Appropriate" (34.24\%) and N "Not Appropriate" (65.76\%). The average soil solum in the Bedadung watershed is $70 \mathrm{~cm}$, while the soil solum required by sengon plants according to plant requirements is $>100 \mathrm{~cm}$. Improving the soil solum for sengon plants is necessary, but the improvement takes a long time. It is reinforced by Sitompul et al. (2018) statement that the rooting media is a heavy limiting factor because it cannot change quickly. The limiting factor of the rooting media cannot be repaired. The soil solum suitability map is presented in Figure 2f.

There are two parameters for nutrient retention in sengon planting requirements, namely CEC, soil $\mathrm{pH}$, and organic C. Cation exchange capacity (CEC) is the ability of the soil to hold cations and as a guide in the availability of nutrients (Wirosoedarmo et al., 2011). The soil CEC suitability class in the Bedadung watershed has three classes, including S1 "Very Suitable" (83.62\%), S2 "Sufficiently Appropriate" (14.58\%), and S3 "Marginal Appropriate" (1.8\%). A high CEC value means that the soil is dominated by clay texture content because the colloids are charged and can absorb positively charged nutrient cations (Wunangkolu et al., 2019). The soil CEC suitability map is shown in Figure $2 \mathrm{~g}$. Soil $\mathrm{pH}$ determines the acid to wet content of the soil with values ranging from 6.04 to 7.8 , with an average of 7.01 ( $\mathrm{Li}$ et al., 2018). The soil $\mathrm{pH}$ suitability class in the Bedadung watershed has four classes, including S1 "Very Suitable" (4.69\%), S2 "Sufficiently Appropriate" 
(58.88\%), S3 "Marginal Appropriate" (24.74\%), and N "Not Appropriate" (11.69\%). Soil that has a soil pH ranging from 6 to 7 is optimal for plant growth (Karapouloutidou and Gasparatos, 2019). The soil pH suitability map can be seen in Figure $2 \mathrm{~h}$. Soil organic $\mathrm{C}$ helps provide an energy source for soil microorganisms, improving soil texture and structure, and reducing erosion (Arunrat et al., 2020). The soil organic-C suitability class in the Bedadung watershed is S1 "Very Suitable" (100\%). Good soil has organic C content between 2$5 \%$ due to improving water holding capacity (WHC), soil aggregate stability, accelerating nutrient cycling, and reducing erosion. The C-Organic suitability map can be seen in Figure $2 \mathrm{i}$.
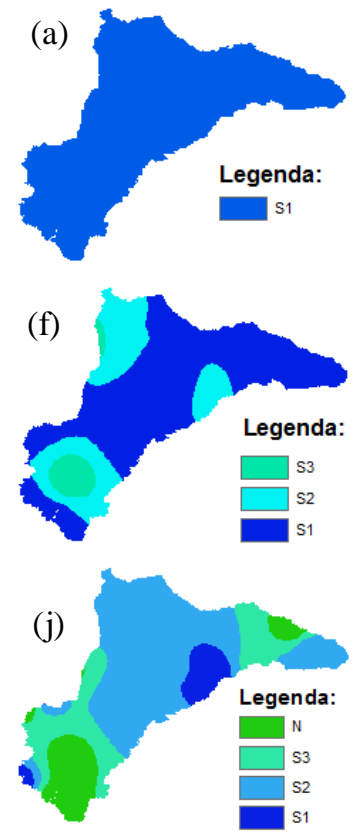

(b)

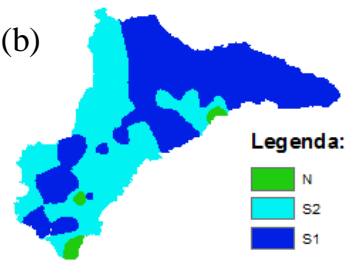

(g)
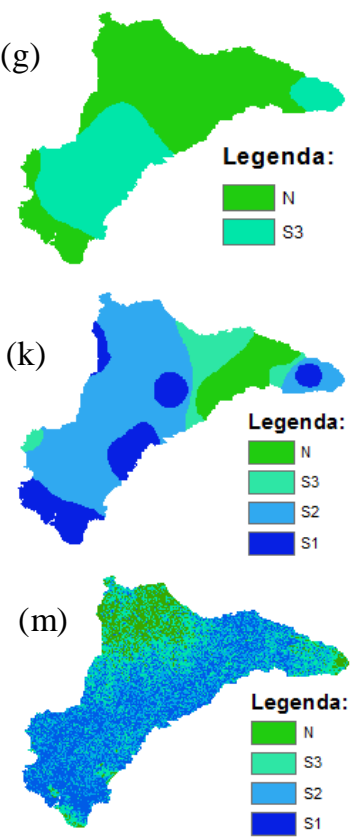

(c)

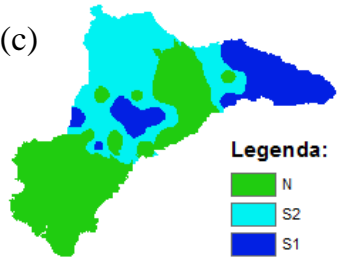

(h)
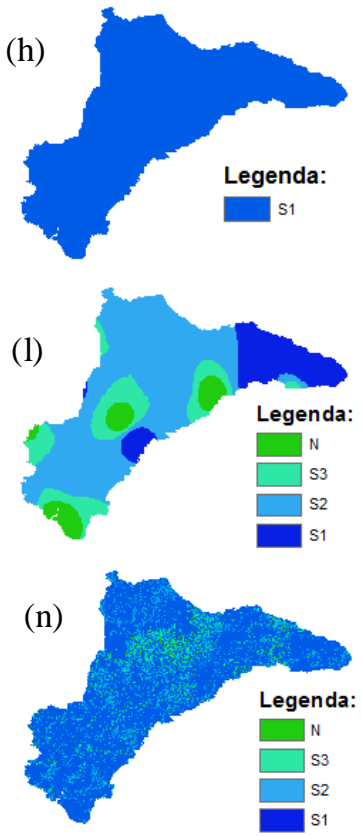
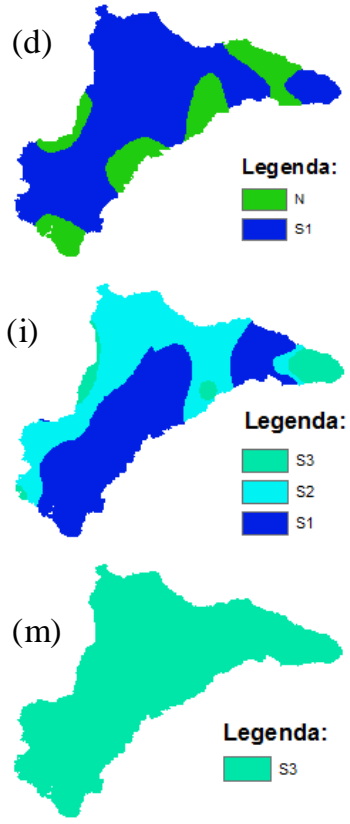

Figure 2 Conformity assessment map (a) temperature; (b) rainfall; (c) dry months; (d) drainage; (e) texture; (f) solum soil; (g) land cec; (h) soil ph; (i) c-organic; (j) soil nitrogen; (k) soil phosphorus; (l) soil potassium; (m) slope; (n) erosion hazard

Nutrients have three parameters: N, P, and K. The high or low value of total $\mathrm{N}$ in each land use depends on organic matter content. Sutedjo (2010) stated that the increase in N-Total soil was obtained directly from the decomposition of organic matter, producing organic acids in the ground. The suitability class $\mathrm{N}$ (Nitrogen) in the Bedadung watershed has four classes, including S1 "Very Suitable" (30.52\%), S2 "Sufficiently Appropriate" (49.81\%), S3 "Marginal Appropriate" (12.27\%), and N "Not Appropriate" (7.40\%). Several studies have stated that sengon belongs to the legume plant group that can increase available $\mathrm{N}$ in the soil (Parotta, 1990; Santoso, 2000; and Zaharah et al., 2008). Weathering of organic matter, one of which comes from a litter for $\mathrm{N}$ input (Harahap et al., 2021). The soil nitrogen suitability map can be seen in Figure $2 \mathrm{j}$. According to Rosmarkam and Yuwono (2002), the increase in available P occurred due to the release of $\mathrm{P}$ from added organic matter; besides that, there was also an indirect effect of organic matter on $\mathrm{P}$ in the adsorption complex or soil attachment. Organic matter reduces $\mathrm{P}$ uptake by iron oxides, aluminum, and colloidal clays in the soil. The suitability class $\mathrm{N}$ (Nitrogen) in the Bedadung watershed has four classes, including S1 "Very Suitable" (14.16 \%), S2 "Sufficiently Appropriate" (55.20\%), S3 "Marginal Appropriate" 
(24.30\%), and N "Not Appropriate" (6.35\%). The soil phosphorus suitability map can be seen in Figure $2 \mathrm{k}$. The average potassium analysis value in the Bedadung watershed is $2.23 \mathrm{me} / 100 \mathrm{~g}$. This value is categorized as very low. Thus, the land suitability class for potassium in the Bedadung watershed is classified as S3 "Marginal Appropriate." Improvement of the suitability of cations is needed with fertilization efforts to increase plant productivity. Lack of $\mathrm{K}$ in plants causes young leaves to be dark green; the edges of the leaves are curled or undergo necrosis between the bones of the leaves, stems, and short books. In addition, the level of plant sensitivity to pests and diseases and extreme weather will increase (Marschner, 1986; Havlin et al., 1999). The soil phosphorus suitability map can be seen in Figure 21.

The hazard of erosion in growing sengon plants has two parameters: the slope and the risk of decay. The characteristics of the slopes are related to the morphological characteristics of the land. Steep slope conditions cause soil erosion to transport nutrients (Zhang et al., 2015). Slope suitability classes in the Bedadung watershed include S1 "Very Suitable" (37.00\%), S2 "Sufficiently Appropriate" (28.56\%), S3 "Marginal Appropriate" (23.35\%), and N "Not Appropriate" (11.10\%). The higher the slope, the greater the erosion potential. The slope suitability map for sengon is presented in Figure $2 \mathrm{~m}$. Erosion will decrease soil fertility because it causes a nutrient leaching process (Murthy et al., 2016). Erosion hazard suitability classes in the Bedadung watershed include S1 "Very Suitable" (79.90\%), S2 "Sufficiently Appropriate" (17.15 \%), S3 "Marginal Appropriate" (5.15\%), and N "Not Appropriate" (1.79\%). Thus, there is no need for conservation measures at the study site because the conditions for planting sengon in the S1 class are "very appropriate". However, for steep-slope conditions, it is necessary to take conservation measures such as making siring terraces and regulating plant density to reduce the risk of erosion (Sadono et al., 2020). The erosion hazard suitability map for sengon plants is presented in Figure 2n.

\section{Evaluation of Land Suitability for Sengon Plants}

Land suitability assessment for sengon plants was carried out using a map consisting of 14 parameters, including temperature, rainfall, dry months, drainage, texture, soil solum, soil KTK, soil $\mathrm{pH}$, C-organic, nitrogen, phosphorus $(\mathrm{P})$, potassium. $(\mathrm{K})$, slope, and erosion hazard are then overlaid to obtain a land evaluation map in the Bedadung watershed. The evaluation map for sengon land in the Bedadung watershed is presented in Figure 3 with grades S2 "Sufficiently Appropriate" (22.23\%), S3 "Marginal Appropriate" (48.07\%), and N "Not Appropriate" (29.70\%).

In Figure 3, sengon plants enter the S3 class "Marginal Appropriate" with the limiting factors are rainfall and soil solum. The limiting factor in the land suitability classification is the presence of parameters with a class that is not by the planting requirements. The limiting factors are divided into two, namely repairable and irreparable (Sadono et al., 2020). Rainfall in the Bedadung watershed is on average $<2000 \mathrm{~mm} /$ year, while sengon plants require $2500-4000 \mathrm{~mm} / \mathrm{year}$ of rain. Thus, it is necessary to provide sufficient rainfall water to improve land suitability. According to (Winasis, 2019) the availability of rainfall water for plants is by making reservoirs or dams, but these improvements require no small amount of funds and time. In supporting operations to obtain additional water apart from rainwater, farmers must use water pumps and irrigation canals. The average soil solum in the Bedadung watershed is $70 \mathrm{~cm}$, while the soil solum required by sengon plants is $>100 \mathrm{~cm}$. Thus it is necessary to improve the soil solum, but the improvement requires a short time. Based on Sitompul et al. (2018), the rooting media is a heavy limiting factor because it cannot change in a short time so that the limiting factor of the rooting media cannot be repaired. 


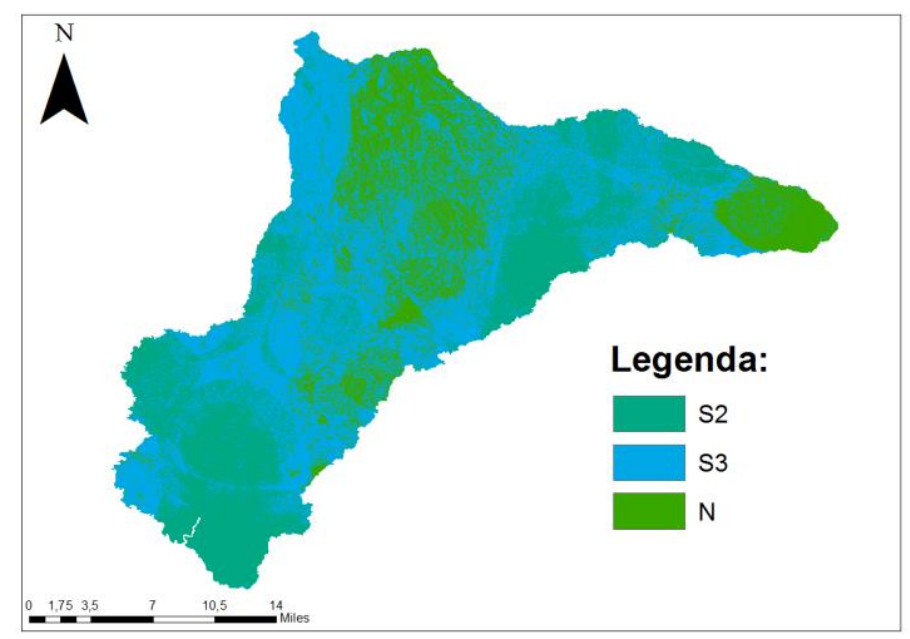

Figure 3 Land suitability evaluation map for sengon plants

\section{CONCLUSION}

Land suitability evaluation using the weighting method of matching and overlaying on sengon plants is dominated by the S3 class "Marginal Appropriate" (48.07\%). The parameters on the land that are the limiting factor for sengon plants are rainfall as a source of water and soil solum. Overcome the limited availability of water due to low rain, dams or reservoirs need to be built, but these repairs require a lot of funds and take a long time. The solution of choice for farmers to get additional water apart from rainwater is recommended to use water pumps and irrigation channels. At the same time, efforts to improve soil depth are difficult to do because it takes a long time. Thus, sengon commodities in Jember Regency will experience sustainability and support industries that use sengon raw materials.

\section{ACKNOWLEDGEMENT}

Acknowledgments are primarily addressed to the internal IsDB batch two supporting grant funds at the University of Jember 2019, which Dr. Idah Andriani chaired, S.TP., M.T., and member lecturer Dr. Sri Wahyuningsih, S.P., M.T., and Dr. Elida Novita, S.TP., M.T. Thanks also to Achmad Fauzan Masudi, S.P., and colleagues who have helped carry out the research.

\section{REFERENCES}

Andriyani I, Wahyuningsih S, Arumsari RS. 2020. Penentuan tingkat bahaya erosi di wilayah das bedadung Kabupaten Jember. Jurnal Ilmiah Rekayasa Pertanian dan Biosistem. 8(1): 1-11. doi: 10.29303/jrpb.v8i1.122.

Arunrat NP, Kongsurakan, Sereenonchai S, Hatano R. 2020. Soil organic carbon in sandy paddy fields of northeast Thailand: a review. Agronomy. 10(8): 1-25. doi: 10.3390/agronomy10081061.

Black CA. 1965. Chemical and Microbiological Properties: Methods of Soil Analysis. Wisconsin (US): Madison American Society.

Dariah A, Wahyunto. 2014. Degradasi lahan di Indonesia: Kondisi existing, karakteristik, dan penyeragaman definisi mendukung gerakan menuju satu peta. Jurnal Sumber daya Lahan. 8(2): 81-93.

Dou FJ, Soriano RE, Tabien, Chen K. 2016. Soil texture and cultivar effects on rice (Oryza sativa, 1.) grain yield, yield components, and water productivity in three water regimes. PLOS ONE. 11(3): 1-12. doi: https://doi.org/10.1371/journal.pone.0150549.

Harahap FS, Harahap DE, Harahap P. 2020. Karakteristik tanah dan evaluasi lahan pada areal penggunaan lain untuk pengembangan tanaman padi sawah di Kecamatan Salak Kabupaten Pakpak Bharat. Ziraa'ah Majalah Ilmiah Pertanian. 45(2): 195-204. 
Harahap FS, Rahmaniah R, Sidabuke SH, Zuhirsyan M. 2021. Evaluasi kesesuaian lahan tanaman sorgum (shorgum bicolor) di kecamatan bilah barat, kabupaten labuhanbatu. Jurnal Tanah dan Sumberdaya Lahan. 8(1): 231-238. doi: 10.21776/ub.jtsl.2021.008.1.26.

Havlin JL, Beaton JD, Tisdale SL, Nelson WL. 1999. Soil Fertility and Fertilizers. An Introduction to Nutrient Management. Sixth Edition. New Jersey (US): Prentice-Hall.

Karapouloutidou S, Gasparatos D. 2019. Biostimulant and organic amendment effects on soil properties and nutrient status of Lactuca sativa in a calcareous saline-sodic soil. Agriculture (Switzerland). 9(8): 1-14. doi: 10.3390/agriculture9080164.

Kome GK, Enang RK, Tabi FO, Yerima BPK. 2019. Influence of clay minerals on some soil fertility attributes: a review. Open Journal of Soil Science. 9(9): 155-188. doi: 10.4236/ojss.2019.99010.

Li D, Nanseki T, Chomei Y, Fukuhara Y. 2018. Impact of Soil chemical properties on rice yield in 116 paddy fields sampled from a large-scale farm in Kinki Region, Japan. IOP Conference Series: Earth and Environmental Science. 185(012026): 1-6.

Liu CW, Sung Y, Chen BC, Lai HY. 2014. Effects of nitrogen fertilizers on the growth and nitrate content of lettuce (Lactuca sativa L.). International Journal of Environmental Research and Public Health. 11: 4427-4440.

Marschner H. 1986. Mineral Nutrition of Higher Plants. London (GB): Academic Press.

Mohr ECJ, van Baren FA, van Schuylenborgh J. 1972. Tropical Soils: A Comprehensive Study of Their Genesis. $3^{\text {rd }}$ ed. The Hague, Netherlands; Paris: Djakarta, Indonesia, Mouton, Ichtiar Baru, Van Hoeve. Pp 5-13.

Murthy IK, Dutta S, Varghese V, Joshi PP, Kumar P. 2016. Impact of agroforestry systems on the ecological and socio-economy system: a review. Global Journal of Science Frontier Research. 16(5): 15-27.

Rimbakita.com. 2021. Hutan Tanaman Industri - Pengertian \& Perkembangan di Indonesia [Internet]. [Accessed $2021 \mathrm{Jul}$ 29]. Available at: https://rimbakita.com/hutan-tanaman-industri/.

Nugroho TA, Salamah Z. 2015. Pengaruh lama perendaman dan konsentrasi biji sengon (Paraserianthes falcataria L.). JUPEMASI-PBIO. 9(8): 230-236.

Parotta JA. 1990. Paraserianthes falcataria (L.) Nielsen - Batai, Moluccan Sau. Puerto Rico (US): USDA Forest Service, Southern Forest Experiment Station, Institute of Tropical Forestry.

Qomaruddin, Sukmono A, Nugraha AL. 2018. Analisis kesesuaian lahan komoditas kehutanan dan perkebunan di wilayah kabupaten banjarnegara dengan metode matching. Jurnal Geodesi Undip. 7(1): 1-13.

Ritung SK, Nugroho A, Mulyani, Suryani E. 2011. Petunjuk Teknis Evaluasi Lahan Untuk Komoditas Pertanian (Edisi Revisi). Bogor (ID): Balai Besar Penelitian dan Pengembangan Sumberdaya Lahan Pertanian, Badan Penelitian dan Pengembangan Pertanian.

Romadlon MM, Hariyanto T. 2014. Analisa perbandingan curah hujan berdasarkan data citra noaa avhrr dengan data curah hujan di lapangan. GEOID. 10(1): 1-7.

Rosmarkam A, Yuwono NW. 2002. Ilmu Kesuburan Tanah. Yogyakarta (ID): Kanisius.

Sadono RD, Soeprijadi, Wirabuana PYAP. 2020. Kesesuaian lahan untuk pengembangan tanaman kayu putih dan implikasinya terhadap teknik silvikultur. Jurnal Pengelolaan Sumberdaya Alam Dan Lingkungan (Journal of Natural Resources and Environmental Management). 10(1): 43-51.

Santoso B. 2000. Studi analisis tanah, daun, dan seresah tanaman sengon (Albizia falcataria L.) pada jenis tanah hapludalf di PT. Perkebunan Nusantara XII (Persero) Pancursari, Malang. Habitat. 11(111): 7691.

Sitompul R, Fitra SH, Rauf A, Rahmawaty dan Simon HS. 2018. Evaluasi kesesuaian lahan pada areal penggunaan lain di Kecamatan Sitellu Tli Urang Julu Kabupaten Pakpak Bharat untuk pengembangan tanaman cabai merah (Capsicum annuum L.). Jurnal Tanah dan Sumberdaya Lahan. 5(2): 829-839.

Sudomo A. 2012. Perkecambahan benih sengon (Falcataria moluccana (MIQ.) Berneby \& J.W. Grimes) pada 4 jenis media. Prosiding SNaPP. Sains, Tekhnologi dan Kesehatan. 3(1): 37-42. 
Sutedjo MM. 2010. Pupuk dan Cara Pemupukan. Jakarta (ID): Rineka Cipta.

Van Reeuwijk LP. 1993. Procedure for Soil Analysis. $4^{\text {th }}$ ed. Wageningen (NL): International soil reference center Wageningen. (ISRIC) technical paper.

Warisno DK. 2009. Investasi sengon: Langkah praktis membudidayakan pohon uang. Jakarta (ID): Gramedia Pustaka Utama.

Wibisono K. 2021. Monitoring kinerja das bedadung Kabupaten Jember, Jawa Timur. Jurnal Geografi. 18(1): $52-59$.

Winasis A. 2019. Analisis hidrologi waduk penjalin guna optimasi d. i. pemali. Syntax Literate: Jurnal Ilmiah Indonesia. 4(3): 1-12.

Wirosoedarmo R, Sutanhaji AT, Kurniati E. 2011. Evaluasi kesesuaian lahan untuk tanaman jagung menggunakan metode analisis spasial land suitability assessment of corn (Zea mays 1.) using spasial analysis method. Agritech. 31(1): 71-78.

Wunangkolu R, Rismaneswati, Lopulisa C. 2019. Karakteristik dan produktivitas lahan sawah irigasi di Kecamatan Duampanua Kabupaten Pinrang. Jurnal Ecosolum. 2(1): 63-69. doi: https://doi.org/10.20956/ecosolum.v8i1.6900.

Zaharah AR, Chintu R, Ziana ZZ, Bah AR, wan Rashidah WAK. 2008. Relative contribution of hedgerow leguminous trees, leaf mulch, and supplementary urea to the yield and $\mathrm{N}$ nutrition of alley maize crops. Management of Agroforestry Systems for Enhancing Resource use Efficiency and Crop Productivity. Austria (AT): IAEA. 15-28.

Zhang Z, Sheng L, Yang J, Chen XA, Kong L, Wagan B. 2015. Effects of land use and slope gradient on soil erosion in a red soil hilly watershed of southern China. Sustainability (Switzerland). 7(10): 1430914325. 